\title{
STRATEGI PEMBELAJARAN PAI DALAM KONTEKS IMPLEMENTASI NILAI-NILAI RELIGIUS DI SMP ALAM BANYUWANGI ISLAMIC SCHOOL
}

\author{
Oleh \\ Miftahul Alimin \\ Universitas Ibrahimy Situbondo, Indonesia \\ alimin92miftahul@gmail.com
}

\begin{abstract}
:
The learning strategy is one of the important components in Islamic education learning. In embedding religious values, a competitive learning strategy is needed so that the objectives of Islamic Education can be realized. SMP Alam Banyuwangi Islamic School is one of the education institutions that apply a special system in learning with a boarding school approach. Through a philosophical approach, this research focuses on uncovering the types of learning strategies at SMP Alam Banyuwangi Islamic School and their implementation in learning in the context of cultivating religious values. The researcher chooses the type of qualitative research in presenting the data according to the research focus with historical, philosophical and theological approaches descriptively. Based on the data and analysis in this research, it can be concluded that Islamic education learning strategy in SMP Alam Banyuwangi Islamic School uses a Contextual Teaching Learning (CTL) approach based on multiple intelligence with the category of studentcentered learning strategies (Student Center Strategies). In addition, in the process, the implementation of Islamic education learning strategy at SMP Alam Banyuwangi Islamic School is actualized in three stages of learning. They are: pre instructional in the form of a learning design formatted in the RPP PAI material, vision, and mission of SMP Alam Bnyuwangi Islamic School; learning activities use the actualized R.U.P.E system with several activity formats; and the evaluation also uses the R.U.P.E system, whose assessment accumulates all learning activities that have been designed at SMP Alam Banyuwangi Islamic School.
\end{abstract}

Keywords: Strategi Pembelajaran, Nilai Religius, SMP Alam, Contextual Teaching Learning

\section{A. Pendahuluan}

Pembelajaran Pendidikan Agama Islam di lembaga-lembaga pendidikan telah kehilangan ruhnya. Pendidikan Agama Islam yang

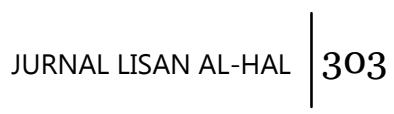


diajarkan untuk menumbuhkan karakter manusia paripurna dalam segala aspek kehidupan, tidak dapat menyelamatkan prilaku amoral dikalangan para pelajar. Sehingga meski Pendidikan Agama Islam telah diajarkan sejak siswa-siswi berada ditingkat satuan pendidikan dasar, prilaku amoral dikalangan pelajar tidak dapat dihindarkan. Seharusnya sebagai umat islam, para pelajar dapat meneladani Rasulullah sebagaimana firman Allah:

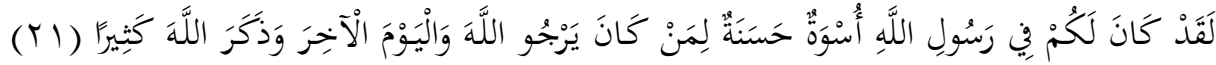

$$
\begin{aligned}
& \text { [الأحزاب/إن }
\end{aligned}
$$

"Sesungguhnya telah ada pada (diri) Rasulullah itu suri teladan yang baik bagimu (yaitu) bagi orang yang mengharap (rahmat) Allah dan (kedatangan) hari kiamat dan Dia banyak menyebut Allah" (al-Ahzab: 21)

Yang menjadi renungan besar bagi stake holder pendidikan adalah apakah yang salah dari pembelajaran Pendidikan Islam di Indonesia selama ini. Pembelajaran pendidikan islam seharusnya didasari dengan tujuan luhur pendidikan islam itu sendiri. Tidak hanya sebagai bahan ajar yang harus diselesaikan oleh siswa-siswi yang beorentasi terhadap nilai rapor saja. Dalam adagium ushuliyah dinyatakan bahwa " al-umuru bi maqashidiha", bahwa setiap tindakan dan aktivitas harus berorentasi pada tujuan dan rencana yang telah ditetapkan. Adagium ini menunjukkan bahwa pendidikan seharusnya berorentasi pada tujuan yang ingin dicapai. Karena itulah, tujuan pendidikan islam menjadi komponen yang harus dirumuskan terlebih dahulu sebelum merumuskan komponen-komponen pendidikan lainnya.

Ahmad D. Marimba menyatakan bahwa tujuan merupakan standar usaha yang dapat ditentukan, serta mengarahkan usaha yang akan dilalui dan merupakan titik pangkal untuk mencapai tujuan-tujuan lain. Di samping itu, tujuan dapat membatasi ruang gerak usaha, agar kegiatan terfokus pada apa yang dicita-citakan, dan yang terpenting lagi adalah dapat memberi penilaian atau evaluasi pada usaha-usaha pendidikan'1.

Tujuan pendidikan islam harus berorentasi pada hakikat pendidikan yang meliputi beberapa aspeknya. Menurut Abdul Mujib tujuan pendidikan islam berorentasi terhadap empat aspek yaitu2: Pertama, tujuan dam tugas hidup manusia. Manusia hidup bukan karena 45-46.

1 Ahmad D. Marimba, Pengantar Filsafat Pendidikan, (Bandung: al-Ma'arif, 1989),

2 Abdul Mujib, Ilmu Pendidikan Islam, (Jakarta: Kencana Prenata Media, 2010), 71 73. Lihat Hasan Langulung, Manusia Dan Pendidikan; Suatu Analisis Psikologi Dan Pendidikan. (Jakarta: Pustaka al-Husna, 1989), 34.

$304 \mid$ JURNAL LISAN AL-HAL 
kebetulan.Ia diciptakan dengan membawa tujuan dan tugas hidup tertentu. Dalam firman Allah dijelaskan,

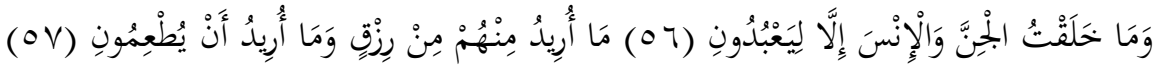

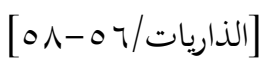

"56. Dan aku tidak menciptakan jin dan manusia melainkan supaya mereka mengabdi kepada-Ku. 57. Aku tidak menghendaki rezki sedikitpun dari mereka dan aku tidak menghendaki supaya mereka memberi-Ku makan."[Ad-Dzariyat: 56-57]

Tujuan diciptakan manusia hanya untuk mengabdi kepada Allah SWT. Indikasi tugasnya berupa ibadah (sebagai 'abd Allah) dan tugas sebagai wakil-Nya dimuka bumi (khalifah Allah). Dengan bahasa lain Moh. Roqib menyatakan bahwa salah satu ruang lingkup pendidikan islam adalah realisasi dwi faungsi manusia; fungsi sebagai hamba Allah dan funsi kekhalifahan yang diberi tugas oleh Allah untuk menguasai, memelihara, memanfaatkan, melestarikan dan memakmurkan alam semesta ${ }^{3}$.

Kedua, memperhatikan sifat-sifat dasar manusia yaitu tentang konsep manusia sebagai makhluk unik yang mempunyai beberapa potensi bawaan, seperti fitrah, bakat, minat, sifat dan karakter. Ketiga, tuntutan masyarakat. Tuntutan ini baik berupa pelestarian nilai-nilai budaya yang berlaku dalam kehidupan masyarakat, maupun pemenuhan terhadap tuntutan kebutuhan hidupnya dalam mengantisipasi perkembangan dunia modern Keempat, dimensi-dimensi kehidupan ideal islam yang mengandung nilai yang dapat meningkatkan kesejahteraan hidup manusia di dunia untuk mengelola dan memanfaatkan dunia sebagai bekal kehidupan diakhirat.

Setelah perumusan tujuan pendidikan islam, hal penting kedua yang membutuhkan perhatian adalah proses pembelajaran. Dalam pembelajaran terdapat unsur belajar yang diartikan sebagai seperangkat kognitif yang mengubah stimulasi lingkungan, melalui pengolahan informasi menjadi kapabilitas baru. Setelah belajar, orang memiliki keterampilan, pengetahuan, sikap dan nilai ${ }^{4}$. Sedangkan mengajar diartikan sebagai proses mengatur dan mengordinasikan lingkungan yang ada disekitar siswa sehingga menumbuhkan dan mendorong siswa melakukan proses belajar. Pada tahap berikutnya mengajar adalah proses

${ }^{3}$ Moh. Roqib, Ilmu Pendidikan Isalam. (Yogyakarta: LkiS, 2009), 22.

4 Hamdani, Strategi Belajar Mengajar, (Bandung: Pustaka Setia, 2010), 71. Lihat Dimyati, M, Belajar dan Pembelajaran. (Jakarta: Rineka Cipta, 2002). 
memberikan bimbingan atau bantuan kepada siswa dalam melakukan proses belajar5.

Apabila hakikat belajar adalah perubahan, hakikat belajar mengajar adalah proses pengaturan yang dilakukan oleh guru. Agar proses belajar mengajar sesuai dengan tujuan yang diharapkan, dibutuhkan metode atau strategi mengajar yang tepat sesuai dengan kapasitas siswa dan konteks materi yang akan di sampaikan. Sehingga dalam pembelajaran pendidikan islam juga dibutuhkan sebuah strategi pembelajaran yang meliputi metode dan teknik atau prosedur yang menjamin siswa mencapai tujuan pembelajaran pendidikan islam yang mempunyai spirit dalam pembentukan karakter religiusitas dan pengamalan nilai-nilai agama.

Oleh karena itu, dalam parakteknya dibutuhkan sebuah sentuhan kreasi dan inovasi strategi dan pendekatan pembelajaran Pendidikan Islam yang tidak hanya sesuai dengan tujuan zaman dan modernisasi pembelajaran, akan tetapi juga bersinergi dengan tujuan pendidikan islam secara keselurahan yang menyangkut terhadap nilai-nilai yang telah diajarkan oleh islam.

SMP Alam Banyuwangi Islamic School yang notabene sebagai satuan pendidikan dengan konsep baru, hadir ditengah masyarakat untuk menjawab tantangan zaman khususnya pendidikan islam yang menawarkan pembelajaran dengan perpaduan antara konsep sekolah umum dan pesantren. Dengan kreativitas inilah pada tahun 2013 lalu, Muhammad Farid S.H.I yang merupakan alumunus Pondok Pesantren Salafiyah Sukorejo masuk dalam nominasi SATU Indonesia Awards sebagai pendiri satuan pendidikan dengan konsep baru. Ajang tahunan yang dipersembahan PT Astra International Tbk ini bertujuan mencari pemuda-pemudi yang memiliki semangat yang sejalan dengan Astra, senantiasa berkontribusi positif untuk lingkungan sekitar dan memberi manfaat bagi masyarakat luas di lima bidang yaitu Pendidikan, Lingkungan, Kesehatan, Teknologi dan Wirausaha6.

Model pembelajaran di SMP Alam Banyuwangi Islamic School yang didirikan pada tahun ajaran 2005/2006 ini, berbeda dengan yang selama ini diterapkan di lembaga - lembaga pendidikan dan pengajaran di Indonesia. Para siswanya masuk kelas hanya 5 hari dalam seminggu yaitu Senin, Selasa, Rabu, Kamis. Pada hari Sabtu, Minggu mereka pulang ke rumahnya masing - masing. Pulang bukan sekedar pulang namun praktek

\footnotetext{
${ }^{5}$ Hamdani, Strategi Belajar Mengajar, (Bandung: Pustaka Setia, 2010), 17.

${ }^{6}$ Diakses dari http://www.astra.co.id/index.php/media_room/press_release/119 pada tanggal 28 desember 2014.

306 JURNAL LISAN AL-HAL
} 
di lembaga sekitar mereka khususnya SD asal mereka.Kenyataannya di lapangan mereka bisa mendirikan lembaga bimbingan dan kursus kursus seperti kursus bahasa Inggris, Arab, Jepang, Mandarin dan rata rata mereka sudah bisa mendapatkan income dari peserta kursus.Mereka juga aktif menggerakkan masjid/ musholla, TPQ, TPA dan gerakan gerakan dakwah Islam lainnya. Ini merupakan salah satu nilai promosi yang efektif untuk menjaring siswa baru di tahun berikutnya7.

\section{B. Metode Penelitian}

Dalam sebuah penelitian, metode merupakan hal yang sangat prinsip untuk diketahui oleh seorang peneliti. Sehingga dengan adanya sebuah metode yang digunakan untuk meneliti, peneliti dapat mengetahui secara menyeluruh terhadap segala hal terkait dengan aktivitias penelitian yang dilakukan. dalam penelitian ini, peneliti menggunakan metode penelitian kualitatif dengan jenis studi kasus yang disajikan menggunakan pendekatan teologis dan filosofis. Desain penelitian kualitatif terdiri dari tiga model, yaitu format deskriptif, format verifikasi, dan format grounded research. Dalam penelitian ini digunakan metode kualitatif dengan desain deskriptif, yaitu penelitian yang memberi gambaran secara cermat mengenai individu atau kelompok tertentu tentang keadaan dan gejala yang terjadi ${ }^{8}$.

Sehingga dengan model format deskriptif ini peniliti ingin menggambarkan secara utuh tentang strategi pembelajaran pai di SMP Alam genteng Banyuwangi Islamic school dalam menumbuhkan nilai-nilai religius tehadap para siswa. selain itu faktor pendukung dan penghambatnya juga akan diungkap dalam penelitian ini. Metode penelitian yang duganakan berdasar pada tujuan penelitian yang dilakukan yaitu: pertama, mendeskripsikan jenis strategi pembelajaran PAI yang diterapkan di SMP Alam Banyuwangi Islamic School, kedua, mendeskripsikan model penerapan dari jenis strategi pembelajaran PAI dalam penanaman nilai religius di SMP Alam Banyuwangi Islamic School, dan ketiga, mendeskripsikan faktor kendala dari penerapan strategi pembelajaran PAI yang berbasis nilai religius di SMP Alam Banyuwangi Islamic School.

7 Diakses dari http://alambis.com/2014/06/13/penerimaan-siswa-baru-tahun2014-2015/ pada tanggal 28 desember 2014

${ }^{8}$ Djam'an Satori, Metodologi penelitian kualitatif, (Bandung: Alfabeta, 2013), h. 2832. 


\section{Kajian Teori}

\section{Strategi Pembelajaran}

Sesungguhnya belajar merupakan ciri khas seorang manusia sehingga manusia dapat dibedakan dengan binatang.Belajar terjadi ketika terjadi interaksi antara individu dan lingkungan, baik lingkungan fisik maupun lingkungan sosial.Hamdani dalam bukunya strategi belajar mengajar menyatakan bahwa lingkungan pembelajaran adalah lingkungan yang merangsang dan menantang siswa untuk belajar'9. Sama halnya dengan belajar, mengajar pun pada hakikatnya merupakan suatu proses, yaitu proses mengatur dan mengorganisasikan lingkungan yang ada disekitar siswa sehingga dapat menumbuhkan dan mendorong siswa melalukan proses belajar.

\section{a. Pengertian Strategi Pembelajaran}

Strategi pembelajaran terdiri dari dua unsur kata yaitu strategi dan pembelajaran. Dalam banyak literatur para pakar memberikan banyak komentar tentang apa itu strategi. Istilah strategi pada awalnya digunakan dalam dunia militer yang diartikan sebagai cara menggunakan seluruh kekuatan militer. Pada masa sekarang, istilah strategi banyak digunakan dalam berbagai bidang kegiatan yang bertujuan memperoleh kesuksesan atau keberhasilan dalam mencapai tujuan ${ }^{10}$.

Strategi berasal dari bahasa Yunani strategia yang berarti ilmu perang atau panglima perang. Berdasarkan pengertian ini, maka strategi adalah seni merancang operasi di dalam sebuah peperangan. Secara umum sering dikemukakan bahwa strategi merupakan suatu teknik untuk mencapai suatu tujuan. Sedangkan dalam administrasi strategi diartikan sebagai upaya yang bersifat makro, menyeluruh jangka panjang, dan didasarkan atas keputusan hasil penalaran ${ }^{11}$.

Sedangkan untuk pembelajaran sendiri Kimble dan Garmezy yang dikutip Mustofa menyatakan bahwa pembelajaran adalah suatu perubahan prilaku yang relatif tetap dan merupakan hasil praktek yang di ulang-ulang. Pembelajaran memiliki makna bahwa subjek belajar harus dibelajarkan bukan diajarkan. Subjek belajar yang dimaksud adalah siswa atau disebut juga pembelajar yang menjadi pust kegiatan belajar ${ }^{12}$.

${ }^{9}$ Hamdani, Strategi Belajar Mengajar, (Bandung: Pustaka Setia, 2011), 2. Lihat Udin, S. Winata Putra, dkk,Strategi belajar mengajar,(Jakarta: Universitas Terbuka, 2002), 2-3.

${ }^{10}$ Abdul Majid, Strategi Pembelajaran, (Bandung: PT Remaja Rosdakarya, 2013), 3.

11 Iskandarwassid dan Dadang Sunendar, Strategi Pembelajaran Bahasa, (Bandung: PT Remaja Rosdakarya, 2010), 2.

12 Muhammad Thobroni dan Arif Mustofa, Belajar dan Pembelajaran, (Jogjakarta: 
Menurut aliran behavioristik pembelajaran adalah usaha guru membentuk tingkah laku yang diinginkan untuk menyediakan lingkungan atau stimulus. Aliran kognitif mendefinisakn pembelajaran sebagai cara guru memberikan kesempatan kepada siswa untuk berpikir agar mengenal dan memahami sesuatu yang dipelajari ${ }^{13}$. Dari banyak pendapat mengenai strategi dan pembelajaran diatas, dapat disimpulkan bahwa strategi pembelajaran adalah suatu teknik dalam mengorganisir proses belajar mengajar untuk mencapai suatu tujuan pembelajaran.

\section{b. Jenis-Jenis Strategi Pembelajaran}

Mengenai pembahasan tentang jenis-jenis strategi pembelajaran atau yang biasa disebut dengan klasifikasi strategi pembelajaran, dalam beberapa literatur yang ditemukan peneliti, para pakar pendidikan mengklasifikasikan jenis-jenis strategi pembelajaran ini secara berbeda; meski secara garis besar terdapat titik temu dari pengklasifikasian yang berbeda ini. Dalam memilih dan menentukan strategi pembelajaran diperlukan pendakatan tertentu. Pendekatan merupakan sudut pandang atau titik tolak untuk memahami seluruh persoalan dalam proses pembelajaran.

Dalam pengklasifikasian strategi pembelajaran dapat digunakan berbagai pendekatan atau dasar klasifikasi. Menurut Raka Joni dalam Mapassoro yang dikutip Abdul Majid menyatakan bahwa klasifikasi strategi pembelajaran bisa dilihat dari berbagai segi, yaitu: 1. Pengaturan guru dan siswa; 2. Pengolahan pesan; 3. Struktur peristiwa belajar mengajar; dan 4. Tujuan belajar mengajar ${ }^{14}$. Iskandarwassih dan Dadang Suhendar dalam bukunya Strategi Pembelajaran Bahasa memetakan strategi pembelajaran kedalam emapat klasifikasi yaitu:

Pertama, Berdasarkan Komponen Program Pengajaran. Strategi pembelajaran yang berdasarkan akan komponen pembelajaran ini terbagi menjadi tiga bagian yaitu ${ }^{15}$ :

1) Teacher Center Strategis adalah strategi pembelajaran yang berpusat pada guru. Dengan demikian pengajar atau pendidik berlaku sebagai sumber informasi yang mempunyai peran yang sangat dominan. Belajar

Ar Ruz Media, 2011), 18.

13Hamdani, Strategi Belajar Mengajar, (Bandung: Pustaka Setia, 2011), 23.

14 Ibid, 69

15 Iskandarwassid dan Dadang Sunendar, Strategi Pembelajaran Bahasa, (Bandung: PT Remaja Rosdakarya, 2010), 26-29. 
dalam pendekatan ini adalah usaha untuk menerima informasi dari pengajar sehingga siswa cenderung pasif.

2) Student Center Strategies, strategi pembelajaran ini mengoptimalkan pembelajaran yang berpusat pada siswa. Sehingga siswa bukan hanya sebagai objek pendidikan melainkan subjek dalam modalitas. Dalam proses pembelajaran peserta didik beruasaha secara aktif mengembangkan dirinya dibawah bimbingan pengajar.

3) Material Center Strategies, strategi pembeajaran yang berpusat pada materi ini bertitik tolak dari pendapat yang mengemukakan bahwa belajar adalah usaha untuk menguwasai dan memperoleh informasi. Strategi pembelajaran yang berpusat pada materi ini menjadikan segala sesuatu yang dapat memberikan informasi bisa dijadikan lingkungan belajar.

Kedua, Berdasarkan Kegiatan Pengolahan Materi. Berdasarkan kegiatan pengolahan pesan atau materi ini, strategi pembelajaran dibedakan ke dalam dua macam, yaitu ${ }^{16}$ :

1) Strategi Pembelajaran Ekspositori, adalah strategi pembelajaran yang lebih berorentasi pada guru, dalam arti semua pesan pembelajaran telah diolah dalam bentuk barang jadi oleh guru untuk selanjutnya disampaikan kepada peserta didik. Guru aktif memberikan informasi tentang pengetahuan seputar materi yang dibahas.

2) Strategi Pembeajaran Heuristik, adalah strategi pembelajaran yang menghendaki siswa untuk terlibat aktif dalam proses pengolahan tujuan pembelajaran. Strategi ini lebih berpusat pada siswa dan bertujuan untuk mengembangkan kemampuan intelektual, berpikir kritis, dan memecahkan masalah dari para siswa. Peran guru dalam pembelajaran sebagai fasilitator.

Ketiga, Berdasarkan Pengolahan Pesan atau Materi. Berdasarkan cara pengolahan materinya strategi pebelajaran dibagi menjadi dua, yaitu: deduksi dan induksi' ${ }^{17}$.

1) Strategi Pembelajaran Deduksi, dalam strategi pembelajaran deduksi materi diolah muali dari hal umum terlebih dahulu menuju hal yang khusus, dari hal-hal yang abstrak ke dalam hal-hal yang nyata, dari konsep-konsep menuju contoh-contoh.

\footnotetext{
70-71.

${ }^{16}$ Abdul Majid, Strategi Pembelajaran, (Bandung: PT Remaja Rosdakarya, 2013),

17 Iskandarwassid dan Dadang Sunendar, Strategi Pembelajaran Bahasa, (Bandung: PT Remaja Rosdakarya, 2010), 31.
}

310 JURNAL LISAN AL-HAL 
2) Strategi Pembelajaran Induksi, strategi pembelajaran induksi adalah pengolahan materi yang dimulai dari khusus ke umum, dari peristiwa yang bersifat individual menuju generalisasi, dari pengalamanpengalaman empiris individual menuju konsep umum.

Keempat, Berdasarkan Cara Memproses Penemuan. Berdasarkan cara memproses penemuan strategi pembelajaran dibedakan atas strategi ekspositoris dan strategi penemuan (discovery) ${ }^{18}$.

1) Strategi Pembelajaran Ekspositoris, sebuah strategi yang berbentuk penguraian yang dapat berupa bahan tertulis atau penjelasan verbal. Pengajar mengolah secara tuntas materi sebelum disampaikan di kelas.

2) Strategi Pembelajaran Discovery, Roetiyah mengemukakan bahwa discovery atau penemuan adalah proses mental peserta didik yang mampu mengasimilasikan sebuah konsep atau prinsip. Dalam strategi pembelajaran ini peserta didik dibiarkan menemukan sendiri atau mengalami proses mental itu sendiri. Pengajar hanya membimbing dan memberikan instruksi.

\section{Pendidikan Agama Islam}

Secara etimologis kata pendidikan berasal dari kata dasar "didik" yang mendapat imbuhan awalan dan akhiran pe-an. Berubah menjadi kata kerja mendidik yang berarrti membantu anak untuk menguasai aneka pengetahuan, ketrampilan, sikap dan nilai yang diwarisi dari keluarga dan masyarakatnya. Istilah ini pertama kali muncul dengan bahasa Yunani yaitu "paedagogiek" yang berarti ilmu menuntun anak ${ }^{19}$.Crow dan Crow yang dikutip Rohman, pendidikan diartikan sebagai proses yang berisi berbagai macam kegiatan yang cocok bagi individu untuk kehidupan sosialnya dan membantu meneruskan adat dan budaya serta kelembagaan sosial dari generasi kegenerasi ${ }^{20}$.

Dari definisi banyak pakar tentang pendidikan dapat disimpulkan bahwa definisi pendidikan dapat dilihat dari dua sudut pandang, yakni pendidikan sebagai proses dan pendidikan sebagai hasil. Sebagai proses, pendidikan didefinisikan sebagai suatau aktivitas interaksi manusia dengan lingkungannya. Sementara sebagai hasil, pendidikan sebagai perubahan yang merupakan hasil interaksi manusia dengan lingkungannya yakni perubahan prilaku ${ }^{21}$.

18 Ibid, 32-33.

19 Arif Rohman, Ilmu Memahami Pendidikan,(Yogyakarta: CV Aswaja Pressindo, 2013), 5 .

${ }^{20}$ Arif Rohman, Ilmu Memahami Pendidikan, 6.

21 Arif Rohman, Ilmu Memahami Pendidikan,39. 


\section{a. Pengertian Pendidikan Islam}

Ada banyak definisi yang dikemukakan oleh para ahli mengenai pendidikan islam yang diantaranya adalah pertama, pendidikan islam merupakan aktifitas pendidikan yang diselenggarakan atau didirikan dengan hasrat dan niat untuk mengejewantahkan ajaran dan nilai-nilai islam. kedua, pendidikan islam adalah sistem pendidikan yang dikembangkan dari dan disemangati atau dijiwai oleh ajaran dan nilai-nilai islam ${ }^{22}$.Dalam dua pengertian pendidikan islam ini maka pengertian pertama lebih menekankan aspek kelembagaan dan program pendidikan islam, dan pengertian yang kedua lebih menekankan pada aspek ruh dan spirit islam yang melekat pada setiap aktifitas pendidikan.

Pendidikan islam pada hakikatnya adalah proses perubahan menuju kearah yang positif. Dalam konteks sejarah, perubahan yang positif ini adalah jalan Tuhan yang sudah dilaksanakan sejak zaman nabi Muhammad Saw. Pendidikan islam dalam konteks perubahan kearah yang positif ini identik dengan kegiatan dakwah yang biasanya dipahami sebagai upaya untuk menyampaikan ajaran islam kepada masyarakat ${ }^{23}$. Dapat dipahami bahwa ruang lingkup pendidikan islam meliputi24:

1) Setiap proses perubahan menuju ke arah kemajuan dan perkembangan berdasarkan ruh ajaran islam;

2) Perpaduan antara pendidikan jasmani, akal (intelektual), mental, perasaan (emosi), dan rohani (spiritual)

3) Keseimbangan antara jasmani-rohani, keimanan-ketakwaan, pikirdzikir, ilmiah-amaliah, materiil-spiritual, individu-sosial, dan duniaakhirat; dan

4) Realisasi dwi fungsi manusia, yaitu fungsi peribadatan sebagai hamba Allah dan fungsi kekhalifahan yng diberi tugas oleh Allah untuk menguasai, melestarikan, dan memakmurkan alam semesta.

22 Muhaimin, Rekonstruksi Pendidikan Islam,(Jakarta: PT RajaGrafindo Persada, 2013), 14-15.

23Ibid, 18-19. Lihat Imam Bawani,Segi-Segi Pendidikan Islam, (Surabaya: Al-Ikhlas, 1987), 73-74. Pendidikan dan pengajaran selalu terkait dengan dakwah islam sehingga sehingga mendidikan merupakan kewajiban bagi setiap muslim untuk meneguhkan iman, memerintahkan kepada kebaikan dan menghilangkan kapada kejelekan. Dakwah juga harus dinamis dalam arti memunculkan kesadaran yang menimbulkan motivasi yang tinggi sehingga setiap muslim bergerak maju demi mencari ridha Allah SWT, jika pendidikan dimaknai sebagai sesuatu yang statis maka pendidikan akan menjadi rutinitas yang kurang bermakna.

${ }^{24}$ Moh. Roqib,Ilmu Pendidikan Isalam,(Yogyakarta: LkiS, 2009), 22. 


\section{b. Komponen-Komponen Pendidikan Islam}

Sebagai sebuah sistem pendidikan islam terdiri dari beberapa komponen yang berhubungan secara fungsionalsatu sama lain. Komponen-komponen itu merupakan pembentuk sistem pendidikan islam. Dalam menelaah hubungan antar komponen tersebut akan dipergunakan suatu analisis sistem yakni analisis yang menyelidiki secara komplek hubungan diantara berbagai komponen yang berkaitan satu sama lain. Komponen-komponen tersebut antara lain: 1. Tujuan pendidikan islam; 2. Tenaga pendidik; 3. Peserta didik; 4 materi pendidikan; 5. Metode pendidikan; dan 6. Evaluasi pendidikan islam ${ }^{25}$.

\section{Nilai-Nilai Religius}

Dalam variabel ini mencakup dua pembahasan, yaitu: Nilai dan Religius. Mengenai nilai, Mulyana mengemukakan empat definisi nilai yang masing-masing memiliki penekanan yang berbeda, yaitu: 1. Nilai sebagai keyakinan yang membuat seseorang bertindak atas dasar pilihannya; 2. Nilai sebagai patokan normatif yang mempengaruhi manusia dalam menentukan pilihannya diantara cara-cara tindakan alternatif; 3. Nilai sebagai keyakinan individu secara psikologis atao nilai patokan normatif secara sosiologi; dan 4. Nilai sebagai konsepsi (sifatnya membedakan individu atau kelompok) ${ }^{26}$.

Untuk religius dalam kamus besar Bahasa Indonesia diartikan sebagai sifat yang terkait dengan nilai dengan nilai-nilai keagamaan, yang tersangkut paut dengan religi. Dalam konteks penelitian ini, karena yang menjadi objek adalah pendidikan islam. Maka yang akan dibahas adalah seputar nilai-nilai normatif yang diajarkan oleh islam. Wahbah al-Zuhaili yang dikutip Abdul mujib dan Jusuf Mudzakir merumuskan bahwa AlQur'an memuat nilai-nilai normatif yang menjadi acuan dalam pendidikan islam. Nilai yang dimaksud terdiri dari pilar utama yaitu: I'tiqadiyah, Khuluqiyyah, dan Amaliyah ${ }^{27}$.

1) I'tiqadiyah, adalah ajaran yang berkaitan dengan pendidikan keimanan, seperti percaya kepada Allah, malaikat, rasul, kitab, hari akhir dan takdir yang bertujuan untuk menata kepercayaan individu. Dalam penjelasannya, Moh Roqib menyatakan dalam pendidikan islam

${ }^{25}$ Baharuddin dan Moh. Sakin, Pendidikan Humanistik, (Jogjakarta: Ar Ruz Media, 2011), 169.

26Ibid, 35.

27 Abdul Mujib dan Jusuf Mudzakir, Ilmu Pendidikan Islam, (Jakarta: Kencana Prenada Media, 2010), 36-37. Lihat Wahbah al-Zuhaili, Ushul al-Fiqh al-Islami, (Damaskus: dar al-Fikr, 1986), Jilid 1, 438-439. 
terdapat ruang lingkup yang diajarkan, sebagai upaya penanaman nilai keislaman. Nilai I'tiqadiyah ini juga bisa disebut dengan nilai akidah (keyakinan) atau keimanan ${ }^{28}$.

2) Khuluqiyyah, nilai khukuqiyyah ini berkaitan dengan etika yang bertujuan untuk membersihkan diri dari prilaku rendah dan menghiasi diri dengan prilaku terpuji. Islam tidak muncul di ruang hampa, tetapi ditengah-tengah kondisi sosial yang penuh pertentangan antar lapisan sosial, kejumudan berpikir, dan kekacaun alam pikiran, terutama mengenai hubungan anatra individu dan penciptanya.. Oleh karena itu dalam beberapa kesempatan Rasulullah Saw menyatakan bahwa " Sesungguhnya aku diutus tidak lain untuk menyempurnakan akhlak yang mulia"29.

3) Amaliyah, nilai ini beraitan dengan pendidikan tingkah laku sehari-hari, baik yang berhubungan antara hamba dengan Sang Pencipta atau pun hubungan manusia dengan sesamanya. Hubungan anatara hamba dan Allah ini di wujudkan dalam bentuk ibadah seperti shalat, puasa, zakat, haji dan nazar yang bertujuan untuk aktualisasi nilai-nilai ubudiyah. Serta pendidikan mu'amalah yang memuat hubungan antara manusia, baik secara individual maupun institusional ${ }^{30}$

\section{Hasil Penelitian}

Dari penelitian yang dilakukan di SMP Alam banyuwai Islamic School, peneliti mendapatkan banyak informasi berupa data dalam bentuk dokumentasi, wawancara dan data hasil observasi yang berkaitan dengan fokus penelitian dalam riset ini. Peneliti memfokuskan tiga pertanyaan bersifat filosofis sesuai dengan pendekatan penelitian. Fokus penelitian pertama mempertanyakan ranah ontologis atau hakikat Strategi pembelajaran PAI yang berbasis penanaman nilai religius di SMP Alam Banyuwangi Islamic School. Untuk rumusan masalah kedua adalah ranah epistimologi yang memfokuskan masalah penelitian terhadap aspek proses dari penerapan strategi pembelajaran PAI yang ada di SMP Alam Banyuwangi Islamic School dalam penanaman nilai religius. Serta dalam pertanyaan ketiga peneliti ingin mengungkap kendala dari strategi pembelajaran PAI yang digunakan di SMP Alam.

${ }^{28}$ Moh. Roqib, Ilmu Pendidikan Isalam, (Yogyakarta: LkiS, 2009), 21.

29 Hery Noer Aly dan Munzier,Watak Pendidikan Islam, (Jakarta: Friska Agung Insani, 2003), 150-152.

30 Abdul Mujib dan Jusuf Mudzakir, Ilmu Pendidikan Islam, (Jakarta: Kencana Prenada Media, 2010), 36. 


\section{Strategi Pembelajaran PAI yang Digunakan di SMP Alam Banyuwangi Islamic School}

Kurikulum merupakan salah satu komponen penting dalam rancangan aktivitas pembelajaran yang dilakukan oleh pendidik. Hal ini dikarenakan kurikulum selalu bersinergi dengan strategi pembelajaran yang akan digunakan pendidik dalam merancang aktivitas pembelajaran.. SMP Alam banyuwangi islamic School yang menerapkan sistem boarding school atau pembelajaran model pesantren menerapkan dua kurikulum yang saling bersinergi. Selain kurikulum nasional, SMP Alam juga menerapkan kurikulum khusus yang diformat sesuai paradigma belajar di SMP Alam. Sehingga pada pembelajaran PAI dalam penanaman nilai religius ini, SMP Alam Banyuwang Islamic School menggunakan kurikulum integrasi yang saling memadukan anatara kurikulum nasional dan kurikulum format khusus SMP Alam.

Adanya penerapan kurikulum integrasi di SMP Alam ini berpengaruh terhadap strategi pembelajaran PAI secara terpisah. Dalam penelitian ini, peneliti telah memetakan strategi pembelajaran yang di gunakan pendidik di SMP Alam Banyuwangi Islamic School dalam penanaman nilai-nilai religius yang saling berintegrasi.

\section{a. Strategi PAI dalam Kurikulum Khusus SMP Alam Banyuwangi Islamic School}

Dari data-data yang diperoleh peneliti, para pendidik di SMP Alam Banyuwangi Islamic School dalam menanamkan nilai religius terhadap peserta didik menggunakan strategi pembelajaran dengan pendekatan kontekstual-aplikakatif yang berbasis training multiple intellegence. Hal ini didasarkan pada paradigma pembelajaran di SMP Alam Banyuwangi Islamic School yang tidak hanya menekankan siswa untuk memahami materi religius dari bahan-bahan ajar saja akan tetapi juga mengharuskan peserta didik mengkontekskan materi religius itu dengan keadaan lingkungan kehidupan sekitar. Sehingga peserta didik tidak hanya dapat mengambil makna dan nilai-nilai religius dari bahan ajar saja, melainkan peserta didik dapat mengambil makna dan nilai regius dari kehidupan peserta didik. Mengenai strategi Contextual Teaching and Learning (CTL) Mohammad Jauhar menyatakan bahwa CTL merupakan proses pembelajaran yang bersifat holistik dan bertujuan membantu siswa untuk memahami makna materi ajar dengan mengaitkannya terhadap konteks kehidupan mereka sehari-hari ${ }^{31}$.

31 Mohammad Jauhar, Implementasi PAIKEM; dari Behavioristik sampai

$$
\begin{array}{l|l}
\text { JURNAL LISAN AL-HAL } & 315
\end{array}
$$


Selain itu dengan paradigma pembelajaran yang berbasis multiple intellegence dalam hal spiritual, para pendiri dan pengurus SMP Alam Bnyuwangi Islamic School berkeinginan out put SMP Alam tidak hanya bisa memahami materi ajaran islam saja, akan tetapi bisa mempraktekkan dan menyebarkan nilai-nilai islam. Sehingga dalam penanaman nilai religius ini peserta didik diharuskan belajar, mengamalkan dan mengajarkan nilai-nilai religius keislaman yang di peroleh di SMP Alam Banyuwangi Islamic School.

\section{b. Strategi Pembelajaran PAI dalam Kurikulum Nasional}

Yang dimaksud dengan PAI dalam kurikulum nasional adalah materi PAI yang wajib diajarkan pada sekolah setingkat SMP sederajat pada umumnya; dimana kurikulum yang digunakan harus menyesuaikan aturan dari kemendikbud. Nilai religius yang diajarkan dalam buku ajar oleh peserta didik selalu berorentasi dengan penanaman nilai religius terhadap peserta didik. Di SMP Alam, pendidik materi PAI yang dalam hal ini diampu oleh Muhammad Qoyyum menerapkan strategi pembelajaran yang variatif sesuai dengan tujuan dan materi yang akan diajarkan kepada peserta didik.

Akan tetapi meski strategi pembelajaran yang digunakan bervariasi, hal itu harus tetap berlandaskan kepada format pembelajaran secara kelembagaan yang menggunakan pendekatan kontekstual-aplikatif. Selain itu pembelajaran PAI di SMP Alam menekankan pendidik untuk selalu kreatif mendesain pembelajaran agar siswa selalu aktif dan senang dalam aktivitas pembelajaran. Sehingga pendidik materi PAI dalam pembelajaran lebih berfungsi sebagai pengawas, pengarah dan evaluator dalam pembelajaran.

Dengan mengacu pada kajian teori didepan, berdasarkan komponen program pengajaran, maka dalam materi PAI kurikulum nasional ini pendidik menggunakan strategi pembelajaran yang berpusat pada siswa (Student Center strategies) dengan pendekatan kontekstualaplikatif. Jadi penekanan pembelajaran dalam menanamkan nilai religius terhadap peserta didik menuntut kekreatifan dan kesadaran peserta didik untuk menggali semua ilmu baik dari materi dalam bahan ajar maupun dari lingkungan hidup.

Hal ini sejalan dengan apa yang dikatakan Martinis Yamin yang menyatakan bahwa pembelajaran CTL merupakan strategi yang aktivitas

Konstruktivisme,(Jakarta: Prestasi Pustaka Karya, 2011), h. 181.

$316 \mid$ JURNAL LISAN AL-HAL 
pembelajarannya berpusat pada peserta didik (student oriented) dan mengembangkan kepampuan berpikir tingkat tinggi, kerjasama, saling membantu peserta didik, menggali, menemukan, mencontoh suatu pengetahuan dan perkembangan belajar dinilai melalui proses ${ }^{32}$.

\section{Implementasi Strategi Pembelajaran PAI dalam Penanaman Nilai-Nilai Religius di SMP Alam Banyuwangi Islamic School}

Dari bahasan di atas diperoleh pemahaman bahwa strategi pembelajaran PAI dalam penanaman nilai religius di SMP Alam baik pada kurikulum khusus SMP Alam maupun pada kurikulum nasional saling berintegrasi. Dimana strategi pembelajaran yang digunakan menggunakan pendekatan Kontekstual-aplikatif yang berbasis multiple intelegence dengan kategori strategi pembelajaran yang berorientasi pada strategi pembelajaran yang berpusat pada siswa.

Berdasarkan data yang di peroleh peneliti, strategi pembejaran yang digunakan di SMP Alam Banyuwangi Islamic School ini dalam penanaman nilai religius terimplementasikan pada tiga tahapan pembelajaran yaitu tahap pra instruksional, tahap aktivitas pembelajaran dan tahap evaluasi. Kemudian dalam pembelajaran CTL terdapat beberapa komponen yang melingkupi yaitu: konstruktivisme, Questioning, Inquiry, Learning community, modeling, reflection dan Authentic Assesment ${ }^{33}$. Dalam pengamatan peneliti, komponen yang tercakup dalam pembelajaran CTL ini juga teraktualisasi ke dalam tiga tahapan pembelajaran yang terancang di SMP Alam meski dengan format dan nama yang variatif.

a. Pra Instruksional

Dalam tahap pra instruksional ini pendidik yang biasa disebut dengan trainer di SMP alam mengumpulkan materi dari sumber bahan ajar yang beragam. Selain dari buku ajar yang menjadi panduan pemerintah dan sumber online, dalam penanaman nilai religius para pendidik juga merujuk pada sumber asli PAI yaitu al-Qur'an, hadist dan kitab klasik karangan pemikir islam. Selain itu dengan pembelajaran berbasis multiple intelegence khususnya SQ, para pendidik mengadopsi informasi pembelajaran dari para trainer yang kemudian dimodifikasi sendiri.

32 Martinis Yamin, Strategi dan Metode dalam Model Pembelajaran,(Jakarta: GP Press Group, 2013), 57.

33 Martinis Yamin, Strategi dan Metode dalam Model Pembelajaran,(Jakarta: GP Press Group, 2013), 56-57. 
Pada tahapan ini juga dirumuskan rancangan tujuan pembelajaran agar aktivitas pembelajaran sesuai dengan tujuan yang telah ditetapkan. Secara garis besar tujuan pembelajaran di SMP Alam dalam penenaman relegius tertuang dalam visi dan misi SMP Alam. Selain itu rumusan tujuan itu juga tertuang dalam Rencana Pelaksanaan Pembejaran (RPP). Dalam rancangan pada tahap pra instruksional ini lebih kepada tinjauan filosofi pembelajaran yang di SMP Alam juga menggunakan konstruktivisme.

b. Aktivitas Pembelajaran

Salah satu tahapan yang juga penting dalam penerapan strategi pembelajaran yang telah dirancang adalah proses dalam aktivitas pembelajaran. Karena dalam aktivitas pembelajaran ini juga tertuang metode dan teknik yang akan digunakan pendidik dalam mengajarkan dan menanamkan nilai keislaman yang terdapat pada PAI sesuai dengan pendekatan pembelajaran yang digunakan.

Di SMP Alam Banyuwangi Islamic School baik pembelajaran PAI dalam kurikulum nasional dan kurikulum khusus SMP Alam terformat saling mendukung sesuai visi dan misi secara kelembagaan. Dimana dalam penanaman nilai-nilai religius kepada peserta didik menggunakan pembelajaran berbasis multiple intelegence sebagai bagian dari pembelajaran pendekatan CTL. Format itu berupa R.U.E P yaitu: Retain What is Tought (mereka tau apa yang mereka pikirkan), Understand what is tought (mereka memahami apa yang mereka pikirkan),Practice It ( mereka mempraktekkan itu) dan be able to explain it to others (mereka mengajarkan kepada yang lainnya).

Retain What is Toughtdan Understand what is tought merupakan proses penanaman nilai ajaran islam kepada peserta didik yang didalamnya terdapat penggunaan metode pembelajaran PAI diantaranya adalah: halaqoh atau english broadcasting yang berupa pembuatan kelompok-kelompok belajar dengan menjadikan salah satu teman sebaya sebagai tutor atau pemandu kelompok. Prinsip pembelajarnya menjadikan siswa aktif dan kreatif dalam proses belajar.

Selain itu digunakan juga metode Mind Maping, song dan game education agar peserta didik bisa senang dalam pembelajaran.Metode ini juga bagian usaha pendidik di SMP Alam mengaktifkan otak kanan peserta didik agar materi pelajaran PAI mudah dipahami dan dihafal oleh peserta didik. Ada juga format kegiatan Tadabur Alam yang merefleksikan materi PAI dengan kehidupan sekitar peserta didik. Dalam komponen pembelajaran CTL rangkaian proses dalam Retain What is Tought dan Understand what is tought masuk kedalam kategori komponen Learning 
Community, Reflection dan Inquiry,

Selanjutanya adalah proses Practice It yang menekankan peserta didik mengamalkan nilai-nilai ajaran islam yang telah diketahui dan dipahami. Metode yang digunakan oleh pendidik di SMP Alam adalah dengan kegiatan yang diberinama dengan pembiasaan amaliyah yang bersifat badaniyahataupun dzikriyah. Proses ini masuk kedalam kategori modeling pendidik kepada peserta didik.

Untuk proses terakhir setelah peserta didik mengetahui, memehami dan mempraktekkan nilai-nilai religius yang telah diajarkan, peserta didik diharuskan mengajarkan nilai-nilai itu kepada peserta didik SMP Alam sendiri maupun peserta didik dilembaga lain. Untuk pegajaran di kalangan teman sendiri teraktualisasi dengan teknik tutor sebaya. Sedangkan pengajaran terhadap peserta didik di sekolah lain yaitu teraktualisasi dengan kegiatan magang di lembaga pendidikan lain yang sudah terjadwal.

c. Tahap evaluasi

Tahapan terakhir dalam aktivitas pembelajaran PAI ini adalah mengevaluasi peserta didik sesuai dengan strategi pembelajaran yang telah dirancang. Di SMP Alam semua proses yang telah terformat dengan konsep R.U.P.E ini selalu dilakukan evaluasi. Jadi peserta didik tidak hanya dinilai melalui ulangan harian atau menjawab soal saja, akan tetapi dinilai dari setiap proses yang telah di programkan dalam strategi pembelajaran PAI.

Sistem evaluasi dengan R.U.P.E yang telah dirancang pendidik di SMP Alam Banyuwangi Islamic School ini menurut peneliti telah sesuai dengan prinsip pembelajaran. Dimana lingkup pembelajaran PAI dalam penenaman nilai religius kepada peserta didik mencakup terhadap aspek kognitif, afektif dan psikomotorik.

\section{Kendala dari Implementasi Strategi Pembelajaran PAI yang Berbasis Nilai Religius}

Dalam segala aktivitas, kendala adalah hal yang menjadi sebuah keharusan. Begitu juga dalam penanaman nilai religius terhadap peserta didik di SMP Alam Banyuwangi Islamic School. Dengan desain pembelajaran yang berbeda dengan pembelajaran di sekolah setingkat SMP pada umumnya, peneliti dapat merangkum beberapa kendala dari beberapa informan berkaitan dengan efektivitas penggunaan strategi pembelajaran PAI di SMP Alam dalam penanaman nilai religius. Beberapa faktor kendala yang dapat terangkum yaitu: 
a. Adat Istiadat Peserta Didik

Peserta didik yang ada di SMP Alam berasal dari daerah yang beragam. Keberagaman daerah ini juga menimbulkan keberagaman adat istiadat dari peserta didik. Dengan keberagaman ini, pendidik mempunyai tingkat kesulitan tersendiri dalam mengkomunkasikan materi belajar terhadap peserta didik dalam aktivitas pembelajaran yang telah dirancang.

b. Alokasi Waktu

Alokasi waktu juga merupakan faktor kendala dalam rancangan strategi pembelajaran PAI di SMP Alam khususnya pembelajaran PAI dalam kurikulum nasional. Dalam format pembelajaran yang berbeda dengan sekolah pada umumnya, alokasi waktu pembelajaran juga mempengerahui aktivitas pembelajarn PAI.

c. Banyak Training ke Lembaga Lain.

Pembelajaran yang berparadigma multiple intelegence menuntut peserta didik di SMP Alam menjadi seorang trainer. Sehingga para trainer atau pendidik di SMP Alam selalu melibatkan peserta didik untuk mengisi training di lembaga pendidikan luar. Dengan intensitas training yang padat juga menjadi kendala strategi pembelajaran yang telah dirancang oleh pendidik PAI.

d. Adaptasi Peserta Didik dan Pendidik Baru

Format pembelajaran khusus di SMP Alam membutuhkan adaptasi tersendiri bagi peserta didik baru maupun pendidik yang baru direkrut di SMP Alam. Hal ini disebabkan rancangan format kegiatan pembelajaran di SMP Alam menekankan siswa aktif dalam pembelajaran tapi juga harus membuat senang peserta didik. Sehingga banyak tawaran format pembelajaran baru dengan paradigma Multiple Intelegence yang menuntut tidak hanya pendidik yang harus kreatif dan inovatif dalam aktivitas pembelajaran. akan tetapi peserta didik juga dituntut demikian.

e. Kesibukan Trainer

Sistem pembelajaran boarding school yang diterapkan di SMP Alam menuntut pengawasan terhadap peserta didik yang juga intens sehingga sistem pembelajaran yang berparadigma R.U.P.E berjalan dengan maksimal. Akan tetapi dengan format pembelajaran PAI yang demikian menyebabkan aktivitas pendidik yang juga padat sehingga itu juga mempengaruhi terhadap efektivitas penerapan strategi pembelajaran PAI di SMP Alam. 


\section{E. Simpulan}

Berdasarkan paparan data dan pembahasan dalam skripsi ini, tentang strategi pembelajaran PAI dalam konteks implementasi nilai-nilai religius di SMP Alam Banyuwangi Islamic School dapat ditarik simpulan sebagai berikut: Pertama, Strategi pembelajaran PAI dalam penanaman nilai-nilai religius di SMP Alam Banyuwangi Islamic School mengacu kepada kurikulum integrasi yang diterapkan. Strategi pembelajaran PAI di SMP alam menggunakan pendekatan Contextual Teaching Learning (CTL)Aplikatif yang berbasis Multiple Intelegence dengan kategori strategi pembelajaran yang berpusat pada siswa (Student Center Strategies).

Kedua, Penerapan strategi pembelajaran PAI di SMP Alam Banyuwangi Islamic School teraktualisasi dalam tiga tahap pembelajaran yaitu: 1) Pra Instruksional; berupa rancangan pembelajaran yang terformat dalam RPP materi PAI, visi, dan misi SMP Alam Bnyuwangi Islamic School. Selain itu juga berupa persiapan materi yang bersumber dari buku ajar, al-qur'an, hadist dan kitab klasik, 2) Aktivitas pembelajaran; menggunakan format R.U.P.E yaitu: Retain What is Tought (mereka mengetahui apa yang mereka pikirkan), Understand what is tought (mereka memahami apa yang mereka pikirkan) yang kedua konsep ini tektualisasi dengan metode halaqoh, english broadcasting, mind maping, song, game aducation, dan tadabur alam. Untuk format Practice It ( mereka mempraktekkan itu) teraktualisasi dengan kegiatan pembiasaan amaliyah badaniyah dan dzikriyah. Sedangkan format be able to explain it to others (mereka mengajarkan kepada yang lainnya) teraktualisasi dengan metode tutor sebaya dan magang di lembaga pendidikan lain, 3) Evaluasi; menggunakan format R.U.P.E yang penilainnya mengakumulasi semua kegiatan pembelajaran yang telah di rancang di SMP Alam Banyuwangi Islamic School. Sehingga peserta didik mempunyai dua nilai raport.

Ketiga, kendala dalam impelementasi strategi pembelajaran PAI dalam penanaman nilai religius meliputi lima faktor yaitu: 1). Adat Istiadat Peserta Didik; 2). Alokasi Waktu; 3). Banyak Training ke Lembaga Lain: 4). Adaptasi Peserta Didik dan Pendidik Baru, dan 5). Kesibukan Trainer.

\section{DAFTAR PUSTAKA}

Ahmadi, Rulam. Pengantar Pendidikan, Asas dan Filsafat Pendidikan. Yogyakarta: Ar-Ruzz Media, 2014.

Al-Fandi, Haryanto. Desain Pemebelajaran yang Demokratis dan Humanis, Yogjakarta: Ar Ruz Media, 2011.

Baharuddin dan Sakin, Moh. Pendidikan Humanistik. Yogyakarta: Ar Ruz 
Media, 2011.

Buseri, Kamreni. Antologi Pendidikan Islam dan Dakwah. Yogyakarta: UII Press, 2003.

Djamarah, Syaiful Bahri dan Zain, Aswan. Strategi Belajar Mengajar. Jakarta: RINEKA CIPTA, 2013.

Hamdani. Strategi Belajar Mengajar. Bandung: Pustaka Setia, 2010.

http://alambis.com/2014/06/13/penerimaan-siswa-baru-tahun-2014-

\section{5/}

http://www.astra.co.id/index.php/media room/press release/119

Iskandarwassid dan Sunendar, Dadang. Strategi Pembelajaran Bahasa. Bandung: PT Remaja Rosdakarya, 2010.

Jauhar, Mohammad, Implementasi PAIKEM; dari Behavioristik sampai Konstruktivisme, Jakarta: Prestasi Pustaka Karya, 2011.

Maelasari, Ferninda. Model Pembelajaran Pendidikan Agama Islam SMP Alternatif Bumi Madan. Salatiga, Tarbiyah, Sekolah Tinggi Agama Islam Negeri Salatiga, 2014.

Marimba, Ahmad. Pengantar Filsafat Pendidikan. Bandung: al-Ma'arif, 1989.

Meleong, Lexy J. Metodologe Penelitian Kualitatif . Bandung: Rosda Karya, 2007.

Muhaimin dan Mujib, Abdul. Pemikiran Pendidikan Islam. Bandung: Trigenda, 1993.

Muhaimin. et. al. Manajemen Pendidikan: Aplikasinya dalam penyusunan Rencana Pengembangan Sekolah/Madrasah. Jakarta: Prenada Media Group, 2011.

Muhaimin. Rekonstruksi Pendidikan Islam. Jakarta: PT RajaGrafindo Persada, 2013.

Mujib, Abdul. Ilmu Pendidikan Islam. Jakarta: Kencana Prenata Media, 2010.

Narbuko, Cholid. et.al. Metodologi Penelitian. Jakarta: Bumi Aksara, 2002.

Ridwan. Metode dan Teknik Menyusun Tesis. Bandung: Alfabeta, 2004.

Rohman, Arif. Ilmu Memahami Pendidikan. Yogyakarta: CV Aswaja Pressindo, 2013.

Roqib, Moh. Ilmu Pendidikan Isalam. Yogyakarta: LkiS, 2009.

Satori, Djam'an. et. al. Metodologi Penelitian Kualitatif. Bandung: Alfabeta, 2013.

Sugiyono. Memahami Penelitian Kualitatif. Bandung: Alfabeta, 2012.

Sumiati. Metode Pembelajaran. Bandung: Wacana Prima, 2008.

Tafsir, Ahmad. Ilmu Pendidikan dalam Perspektif Islam. Bandung: Rosdakarya, 1994.

$322 \mid$ JURNAL LISAN AL-HAL 
Thobroni, Muhammad dan Mustofa, Arif. Belajar dan Pembelajaran. Jogjakarta: Ar Ruz Media, 2011.

Wibowo, Agus. Manajemen Pendidikan Karakter di Sekolah. Yogyakarta: Pustaka Pelajar, 2013.

Yamin, Martinis, Strategi dan Metode dalam Model Pembelajaran, Jakarta: GP Press Group, 2013.

Zubaedi. Desain Pendidikan Karakter. Jakarta, Kencana Prenada Media Group, 2013. 
"Strategi Pembelajaran Pendidikan Agama Islam"

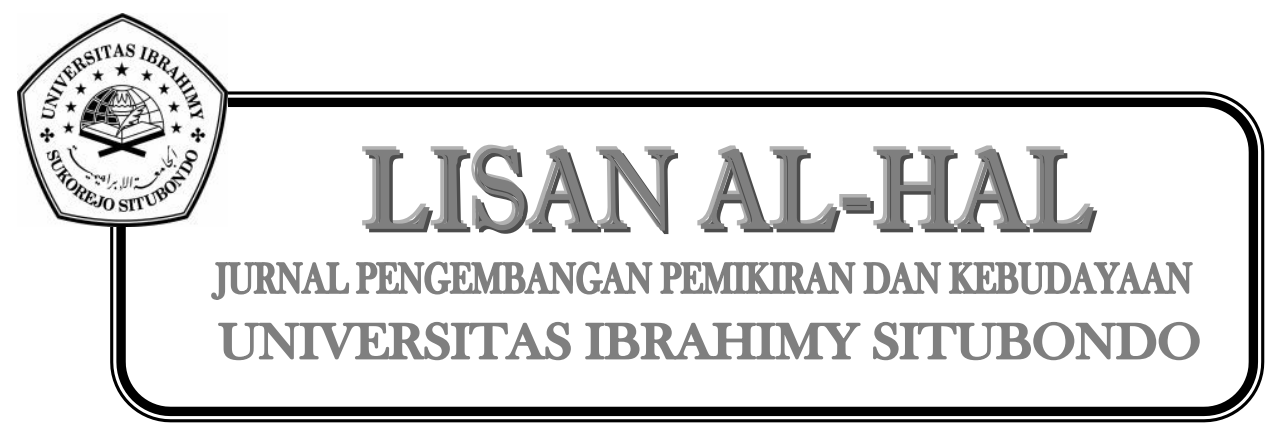

324 JURNAL LISAN AL-HAL 